Jurnal Artikel

\title{
Pengaruh Bentuk Sprue Well Pada Gatting System Terhadap Aliran Fluida Logam Dan Nilai Kekerasan Pada Pengecoran Aluminium Daur Ulang Menggunakan Sand Casting
}

\author{
Sri Endah Susilowati ${ }^{1}$, Sopyan Permana ${ }^{2}$ \\ ${ }^{1,2}$ Program Studi Teknik Mesin Universitas 17 Agustus 1945 Jakarta \\ sriendah.susilowati@yahoo.com ${ }^{1}$, sopyanpermana8@gmail.com ${ }^{2}$ \\ *Corresponding author - Email : sriendah.susilowati@yahoo.com
}

Artkel Info - : Received : 30 Jul 2020; Revised : 28 Aug 2020; Accepted: 30 Aug 2020

\begin{abstract}
Gatting System merupakan sistem saluran pada cetakan untuk proses pengecoran logam, di dalam sistem saluran terdapat salah satu bagian yang sangat berpengaruh terhadap aliran fluida logam yaitu sprue well. Sprue Well ini berfungsi untuk menyerap energi kinetik dan meminimalisir terjadinya turbulensi yang dapat mempengaruhi kualitas dari produk hasil pengecoran dengan cetakan pasir.

Penelitian ini menggunakan material Aluminium daur ulang dengan variasi gatting system pada sprue well dengan bentuk balok, silinder dan setengah bola dan menggunakan metode sand casting serta menuangkan cairan logam dengan temperatur $660 \mathrm{o} C$.

Hasil penelitian menunjukkan sistem saluran dengan sprue well berbentuk balok, silinder serta setengah bola mempunyai nilai kecepatan aliran fluida logam aluminium dan bilangan reynold masingmasing yaitu $183 \mathrm{~cm} / \mathrm{s}$ dan 2.236,36 ( aliran transisi ), $202 \mathrm{~cm} / \mathrm{s}$ dan 2.468,4 (aliran transisi ), serta 225 $\mathrm{cm} / \mathrm{s}$ dan 2.749,5 (aliran transisi). Kemudian Spesimen aluminium hasil pengecoran sand casting dengan sistem saluran berbentuk sprue well balok, silinder dan setengah bola masing- masing mempunyai nilai kekerasan yaitu 175,4 HLD, 148,2 HLD dan 121,4 HLD.
\end{abstract}

Kata kunci: gatting system, aluminium, bentuk sprue well, sand casting, uji kekerasan

\section{Abstract}

The gatting system is a channel system in the mold for the metal casting process, in the channel system there is one part that is very influential on the flow of metal fluids, namely Sprue Well. Sprue Well functions to absorb kinetic energy and minimize the occurrence of turbulence which can affect the quality of casting products with sand molds.

This research uses recycled aluminum material with a variation of the gatting system on the sprue well in the form of a block, cylinder and half ball and uses the sand casting method and pouring liquid metal with a temperature of $660 \mathrm{o} C$.

The results showed that the channel system with sprue wells in the form of blocks, cylinders and half spheres had flow velocity values of aluminum metal fluid and reynold numbers with values of $183 \mathrm{~cm} / \mathrm{s}$ and 2,236.36 (transition flow), $202 \mathrm{~cm} / \mathrm{s}$ and 2,468.4 (transition flow), as well as $225 \mathrm{~cm} / \mathrm{s}$ and 2,749.5 (transition flow). Then the aluminum specimens from sand casting with a channel system in the form of sprue well beams, cylinders and half balls each have a hardness value of 175.4 HLD, 148.2 HLD and 121.4

Keywords: Gatting System, Aluminum, Sprue Well Shape, Sand Casting, Hardness

\section{Pendahuluan}

\subsection{Latar Belakang}

Pengecoran logam merupakan proses awal yang paling penting dalam industri 
logam, teknologi pengecoranpun semakin menunjukkan perkembangan sesuai dengan kebutuhan industri logam itu sendiri dan proses pengecoran masih digunakan sampai sekarang untuk memperoleh bentuk logam sesuai dengan yang di minati.

Dalam sistem dan proses pengecoran tidak lepas dari cetakan, cetakan inilah yang bisa mempengaruhi logam dari segi kekerasan dan bentuk logam. Untuk cetakan yang lazim dipakai sampai sekarang adalah cetakan pasir (sand casting).

Di dalam cetakan pasir terdapat gatting system yang berfungsi sebagai tempat mengalirnya cairan logam, karena itu gatting system perlu diperhatikan dari bentuk salurannya agar cairan logam dapat membentuk produk sesuai bentuk dan kualitas yang baik.

Salah satu unsur penting yang perlu diperhatikan dalam memproduksi produk pengecoran yang berkualitas adalah perancangan saluran (gating design). Beberapa bagian dalam desain sistem saluran meliputi cawan tuang, saluran turun (sprue), saluran pengalir (runner), saluran penambah (riser), dan saluran masuk (ingate). Upaya penelitian secara meluas telah banyak dilakukan dalam rangka mempelajari pengaruh perancangan saluran pada pola aliran logam cair saat memasuki cetakan. Penelitian - penelitian tersebut menunjukkan bahwa perancangan sistem saluran yang optimal dapat mengurangi turbulensi pada aliran logam cair, meminimalisasi udara yang terjebak, inklusi pasir, lapisan oksida dan terak (Shafiee et al., 2009).

Pada penelitian ini akan mempelajari salah satu bagian dari sistem saluran yaitu sprue well. Sprue Well adalah bagian dari gatting system yang letaknya dibawah saluran turun ( sprue) yang mempunyai fungsi yaitu untuk menyerap energi kinetik logam cair saat keluar dari saluran turun ( sprue), sehingga turbulensi dari aliran logam yang melewati saluran mengalir dapat dieliminasi atau diperkecil.

\subsection{Tujuan Penelitian}

Penelitian ini bertujuan untuk :

1.Meneliti aliran fluida logam pada sistem saluran dengan bentuk sprue well balok, silinder dan setengah bola pada pengecoran aluminium daur ulang menggunakan sand casting.

2. Meneliti nilai kekerasan spesimen aluminium daur ulang hasil pengecoran sand casting dengan sistem saluran pada sprue well berbentuk balok, silinder dan setengah bola.

\subsection{Batasan Masalah}

Batasan masalah dalam penelitian ini adalah :

1.Material yang digunakan adalah aluminium daur ulang/ kaleng minuman.

2. Temperatur cairan logam yaitu $660^{\circ} \mathrm{C}$.

3. Cetakan yang digunakan yaitu cetakan pasir dengan komposisi pasir silika $80 \%$, bentonite $10 \%$ dan air $10 \%$.

4. Melakukan perhitungan aliran fluida logam pada sistem saluran dengan bentuk sprue well balok, silinder dan setengah bola.

5.Spesimen yang akan diuji kekerasannya adalah spesimen aluminium hasil pengecoran sand casting dengan sistem saluran pada sprue well berbentuk balok, silinder dan setengah bola dengan menggunakan metode Leeb Hardness

\subsection{Tinjauan Pustaka}

Penelitian yang dilakukan oleh Yosua Kristiadi, Victor Y. Risonarta dan Juliana Anggono (2017) tentang gatting system pada proses pengecoran memiliki pengaruh penting terhadap cacat porositas dan shrinkage. Porositas dan shrinkage terendah terdapat pada spesimen dengan variasi gatting system panjang runner 60 $\mathrm{mm}$ dan radius top sprue well $5,00 \mathrm{~mm}$ dengan nilai densitas $8,96 \mathrm{~g} / \mathrm{cm} 3$.

Penelitian yang dilakukan oleh Albert Wibowo, Juliana Anggono, dan Victor Y. Risonarta (2016) tentang radius sprue well atas dan panjang runner untuk mengetahui 
perbedaan waste material dan porositas masing - masing variasi. Dari studi literatur dan percobaan yang telah dilakukan didapat bahwa bentuk gatting sangat mempengaruhi laju aliran logam cair, yang akhirnya akan mempengaruhi jumlah porositas dan waste material dari spesimen. Setelah penelitian selesai dilakukan, dapat dilihat porositas terkecil ada pada variasi radius $5 \mathrm{~mm}$ pada panjang runner $7 \mathrm{~cm}$, dan yield waste terbanyak pada panjang runner $5 \mathrm{~cm}$ pada radius 10 $\mathrm{mm}$, hal ini dikarenakan aliran logam menjadi turbulen karena desain gating yang tidak optimal.

Penelitian yang dilakukan oleh L.H. Ashar,H. Purwanto, dan S.M.B. Respati (2012) tentang tiga macam sitem saluran dengan temperatur tuang $660^{\circ} \mathrm{C}$. Metode penelitian dengan cara tiga model sistem saluran. Hasil menunjukkan bahwa dari ketiga model sistem saluran tersebut mempunyai cacat yang berbeda, untuk pola saluran $\mathrm{B}$ dan $\mathrm{C}$ terdapat cacat penyusutan (shrinkage) di tengah-tengah coran, sedangkan untuk pola saluran A tidak terdapat cacat penyusutan akan tetapi terdapat cacat drop (tonjolan pada hasil coran). Hasil Struktur mikro pengecoran pada pola saluran $\mathrm{A}, \mathrm{B}$ dan $\mathrm{C}$ masingmasing terdapat cacat porositas dimana pada pola saluran $\mathrm{C}$ lebih sedikit cacat porositasnya dibandingkan dengan pola saluran A dan paling banyak cacat porositasnya terdapat pada pola saluran B dan pada hasil uji kekerasan Untuk nilai kekerasan pola saluran A lebih tinggi nilai kekerasannya 75,8 BHN dibanding dengan Pola saluran B 70,8 BHN dan pola saluran C 70,73 BHN.

\section{Landasan Teori}

\subsection{Metode Sand Casting (Pengecoran dengan cetakan pasir)}

Proses pembentukan benda kerja dengan metoda penuangan logam cair kedalam cetakan pasir (sand casting), secara sederhana cetakan pasir ini dapat diartikan sebagai rongga hasil pembentukan dengan cara mengikis berbagai bentuk benda pada bongkahan dari pasir yang kemudian rongga tersebut diisi dengan logam yang telah dicairkan melalui pemanasan (molten metals). Cetakan pasir merupakan cetakan yang paling banyak digunakan, karena memiliki keunggulan :

1. Dapat mencetak logam dengan titik lebur yang tinggi, seperti baja, nikel dan titanium.

2. Dapat mencetak benda cor dari ukuran kecil sampai dengan ukuran besar.

3. Jumlah produksi dari satu sampai jutaan.

Tahapan pengecoran logam dengan cetakan pasir ditunjukkan pada Gambar 2.1 sebagai berikut :

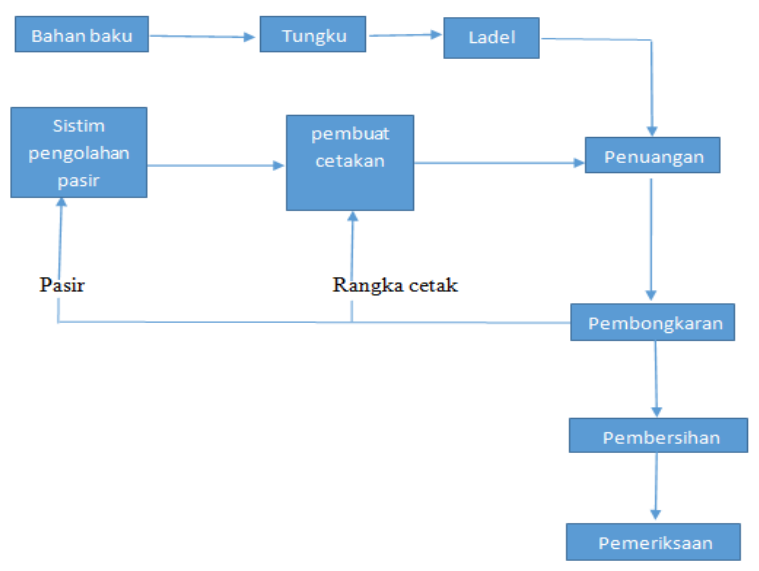

Gambar 2.1 Skema Pengecoran Logam

\subsection{Pola}

Surdia (2000) menyatakan pola diperlukan dalam pembuatan coran. Pola yang dipergunakan untuk pembuatan cetakan benda coran dapat digolongkan menjadi pola logam dan pola kayu (termasuk pola plastik). Pola logam dipergunakan agar dapat menjaga ketelitian ukuran benda coran, terutama dalam masa produksi, sehingga unsur pola bisa lebih lama dan produktivitas lebih tinggi. Bahan dari pola logam bisa bermacam-macam sesuai dengan penggunaannya. Sebagai contoh, logam tahan panas seperti : besi cor, baja cor, dan paduan tembaga adalah cocok untuk pola pada pembuatan cetakan kulit, sedangkan paduan ringan adalah mudah diolah dan dipilih untuk pola yang dipergunakan untuk masa produksi dimana 
pembuatan cetakan dilakukan dengan tangan. Pola kayu dibuat dari kayu, murah, cepat dibuatnya dan mudah diolahnya dibanding dengan pola logam. Oleh karena itu pola kayu umumnya dipakai untuk cetakan pasir. Faktor penting untuk menetapkan macam pola adalah proses pembuatan cetakan dimana pola tersebut dipakai, dan lebih penting lagi pertimbangan ekonomi yang sesuai dengan jumlah dari biaya pembuatan cetakan dan biaya pembuatan pola.

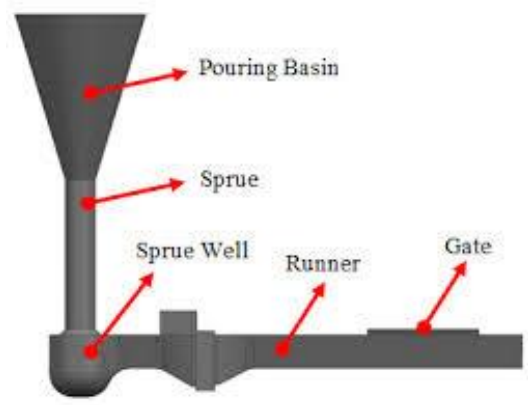

Gambar 2.2 Pola Saluran

\subsection{Pasir Cetak}

Pasir cetak yang paling lazim digunakan adalah pasir gunung, pasir pantai, pasir sungai, dan pasir silika yang disediakan alam. Pasir cetak memerlukan sifat-sifat yang memenuhi persyaratan sebagai berikut :

1. Mempunyai sifat mampu bentuk .

2. Permeabilitas yang cocok.

3. Distribusi besar butir yang cocok.

4. Tahan terhadap temperatur logam yang dituang.

5. Komposisi yang cocok.

6. Mampu dipakai lagi.

7. Pasir harus murah.

\subsection{Pencairan Logam}

Logam dapat dicairkan dengan jalan memanaskan hingga mencapai temperatur titik lelehnya. Berat jenis logam cair besi cor $6,8 \mathrm{gr} / \mathrm{cm} 3$ sampai $7,0 \mathrm{gr} / \mathrm{cm} 3$, paduan alumunium $(2,2-2,3) \mathrm{gr} / \mathrm{cm} 3$, paduan timah $(6,6-6,8) \mathrm{gr} / \mathrm{cm} 3$. Karena berat jenis logam tinggi maka aliran logam memiliki kelembaban dan gaya tumbuk yang besar.

Kekentalan logam tergantung temperaturnya, semakin tinggi temperatur kekentalannya semakin rendah. Berikut daftar kekentalan berbagai macam logam.

Tabel 2.1 Koefisien kekentalan logam cair dan tegangan permukaan

\begin{tabular}{|c|c|c|c|c|c|c|}
\hline Bahan & $\begin{array}{c}\text { Titik cair } \\
\left({ }^{\circ} \mathrm{C}\right)\end{array}$ & $\begin{array}{c}\text { Beratjenis } \\
\left(\mathrm{g} / \mathrm{cm}^{3}\right)\end{array}$ & $\begin{array}{c}\text { Koefisien } \\
\text { kekentalan } \\
(\mathrm{g} / \mathrm{cm} \text {.detik })\end{array}$ & $\begin{array}{c}\text { Koefisien } \\
\text { kekentalan } \\
\text { kinematik } \\
(\mathrm{cm} / \text { detik })\end{array}$ & $\begin{array}{c}\text { Tegangan } \\
\text { permukaan } \\
(\mathrm{dine} / \mathrm{cm})\end{array}$ & $\begin{array}{c}\text { Tegangan } \\
\text { permukaan } \\
\text { Beratjenis }\end{array}$ \\
\hline Air & 0 & 0.9982 & 0.010046 & 0.010064 & 72 & 72 \\
\hline Air Raksa & -38.9 & 13.56 & 0.01547 & 0.00114 & 465 & 34.5 \\
\hline Tin & 232 & 5.52 & 0.01100 & 0.00199 & 540 & 97.8 \\
\hline Timbal & 327 & 10.55 & 0.01650 & 0.00156 & 450 & 42.6 \\
\hline Seng & 420 & 6.21 & 0.03160 & 0.00508 & 750 & 120 \\
\hline \hline Alumunium & 660 & 2.35 & 0.0055 & 0.00234 & 520 & 220 \\
\hline Tembaga & 1033 & 7.84 & 0.0310 & 0.00395 & 581 & 74 \\
\hline Besi & 1537 & 7.13 & 0.000 & 0.00560 & 970 & 136 \\
\hline Besi Cor & 1170 & 6.9 & 0.016 & 0.0023 & 1150 & 167 \\
\hline
\end{tabular}

\subsection{Aliran Logam Cair}

Aliran logam cair termasuk kelompok aliran inkompresibel (seperti air). Tetapi ada hal - hal yang membedakannya yaitu :

1.Cairnya suatu logam dipengaruhi oleh temperatur dan akan cair seluruhnya pada temperatur tinggi, sedangkan pada temperatur rendah berbeda dengan air karena pada temperatur rendah terdapat inti- inti kristal.

2.Berat jenis logam cair lebih besar daripada berat jenis air, sehingga menyebabkan perbedaan aliran pada logam dimana aliran logam cair mempunyai kelembaman dan gaya tumbuk yang besar.

3. Air dapat menyebabkan permukaan dinding wadah basah, sedangkan logam cair tidak. Oleh karena itu apabila logam cair mengalir diatas permukaan cetakan pasir, ia tidak meresap ke dalam cetakan pasir asalkan jarak antara partikel- partikel pasir cukup kecil.

Kekentalan dari logam cair sangat berpengaruh terhadap aliran logam cair yang nantinya akan digunakan proses pengecoran. Kekentalan ini juga tergantung pada temperatur dimana pada temperatur tinggi kekentalan menjadi rendah dan juga sebaliknya yaitu kekentalan tinggi pada temperatur rendah. Oleh karena itu apabila kekentalan tinggi, 
maka akan menyebabkan logam cair sukar mengalir atau kehilangan mampu alir.

Untuk menghitung kecepatan aliran logam cair dapat menggunakan persamaan kontinuitas dimana rumusnya sebagai berikut :

$\mathrm{Q}=\mathrm{V}_{1} \cdot \mathrm{A}_{1}=\mathrm{V}_{2} \cdot \mathrm{A}_{2}$

Dimana :

$\mathrm{A}_{1}=$ Luas penampang $1\left(\mathrm{~mm}^{2}\right)$

$\mathrm{V}_{1}=$ Kecepatan Fluida pada Penampang 2 $\left(\mathrm{mm}^{2}\right)$

$\mathrm{A}_{2}=$ Luas penampang $2\left(\mathrm{~mm}^{2}\right)$

$\mathrm{V}_{2}=$ Kecepatan fluida pada penampang 2 $\left(\mathrm{mm}^{2}\right)$

$\mathrm{Q}=$ Debit Fluida $\left(\mathrm{mm}^{3} / \mathrm{s}\right)$

Sedangkan untuk dapat menghitung

debit digunakan rumus :

$\mathrm{Q}=\mathrm{V} / \mathrm{t}$

Dimana :

$\mathrm{Q}=$ Debit Fluida $\left(\mathrm{mm}^{3} / \mathrm{s}\right.$

$\mathrm{V}=$ Volume Fluida $\left(\mathrm{mm}^{3}\right)$

$\mathrm{t}=$ Waktu ( sekon )

Untuk menentukan jenis aliran fluida, harus menentukan bilangan Reynolds terlebih dahulu . Bilangan Reynolds adalah rasio antara gaya inersia (vs $\rho$ ) terhadap gaya viskos $(\mu / \mathrm{L}) \quad$ yang mengkuantifikasikan hubungan kedua gaya tersebut dengan suatu kondisi aliran tertentu. Bilangan ini digunakan untuk mengidentikasikan jenis aliran yang berbeda, misalnya laminar, turbulen atau transisi.

Bilangan Reynold merupakan salah satu bilangan tak berdimensi yang paling penting dalam mekanika fluida dan digunakan, seperti halnya dengan bilangan tak berdimensi lain, untuk memberikan kriteria untuk menentukan dynamic similitude. Jika dua pola aliran yang mirip secara geometris, mungkin pada fluida yang berbeda dan laju alir yang berbeda pula, memiliki nilai bilangan tak berdimensi yang relevan, keduanya disebut memiliki kemiripan dinamis.

$\operatorname{Re}=\frac{\rho \cdot v \cdot d}{\mu}=\frac{\text { Gaya Inersia }}{\text { Viskositas }}$

Jika $\mathrm{v}=\mu / \rho$ maka $\frac{1}{v}=\frac{\rho}{\mu} ;$ Sehingga :
$\operatorname{Re}=\frac{v \cdot d}{v}$

Dimana:

$\mathrm{Re}=$ bilangan renolds

$\mathrm{v}=$ kecepatan fluida, $(\mathrm{cm} / \mathrm{s})$

$\mathrm{d}=$ diameter penampang $(\mathrm{cm})$

$\mu=$ viskositas absolut fluida dinamis, (g/ cm.s)

$v=$ viskositas kinematik fluida: $v=\mu / \rho$

$\rho=$ kerapatan (densitas) fluida. $\left(\mathrm{g} / \mathrm{cm}^{3}\right)$

Dilihat dari kecepatan aliran, dapat diasumsikan/dikategorikan sbb:

1. Aliran laminar bila aliran tersebut mempunyai bilangan Re kurang dari 2000.

2. Aliran transisi berada pada pada bilangan $\operatorname{Re}(2000$ - 4000 )biasa juga disebut sebagai bilangan Reynolds kritis, sedangkan

3. Aliran turbulen mempunyai bilangan Re lebih dari 4000.

Untuk menentukan Diameter hidrolik adalah empat kali rasio dari luas penampang aliran dibagi dengan keliling terbasahi (P) dari pipa. Diameter hidrolik ini mewakili suatu panjang karakteristik yang mendefinisikan ukuran sebuah penampang dari bentuk yang ditentukan. Faktor 4 ditambahkan dalam definisi Dh. Sehingga diameter hidrolik pipa berpenampang persegi sama dengan diameter pipa berpenampang bundar.

Concentric Annulus

$D_{h}=D_{2}-D_{1}$

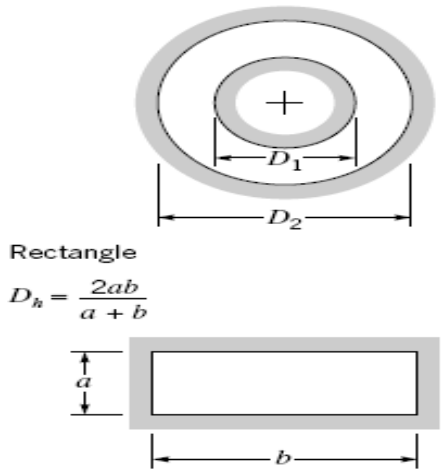

Gambar 2.3 Bentuk saluran

\subsection{Aluminium}

Aluminium ialah unsur melimpah ketiga terbanyak dalam kerak bumi (sesudah oksigen dan silicon), mencapai $8,2 \%$ dari massa total. Bijih yang paling penting untuk produksi alumunium ialah 
bauksit, yaitu alumnium oksida terhidrasi yang mengandung 50 sampai $60 \% \mathrm{Al}_{2} \mathrm{O}_{3}$, 1 sampai $20 \% \mathrm{Fe}_{2} \mathrm{O}_{3}$, dan 1 sampai $10 \%$ silikat sedikit sekali titanium, zirconium, vanadium, dan oksida logam transisi yang lain, dan sisanya 20 sampai $30 \%$ adalah air.

Tabel 2.2 Sifat-sifat Fisik dan Kimia dari alumunium

\begin{tabular}{cc}
\hline Item & Kualifikasi \\
\hline Nomor Atom & 13 \\
Nomor Massa & 26,9815 \\
Bentuk Kristal $\left(25^{\circ} \mathrm{C}\right)$ & Kubus Pusat \\
& Muka \\
Density & $2,699 \mathrm{~g} / \mathrm{cm}^{3}$ \\
Struktur Atom Terluar & $3 \mathrm{~S} 23 \mathrm{P} 1$ \\
Titik Leleh $(1 \mathrm{~atm})$ & $660,1^{\circ} \mathrm{C}$ \\
Titik Didih $(1 \mathrm{~atm})$ & $2327^{\circ} \mathrm{C}$ \\
Panas Peleburan & $94,6 \mathrm{kal} / \mathrm{g}$ \\
Panas Jenis & $0,280 \mathrm{kal} / \mathrm{g}^{\circ} \mathrm{C}$ \\
\hline
\end{tabular}

\subsection{Pengujian Kekerasan (Leeb}

\section{Rebound Hardness)}

Nilai kekerasan (HL) dihitung dari rasio kecepatan tumbukan dan rebound. Nilai kekerasan (HL) ini kemudian dapat diubah oleh perangkat lunak untuk menampilkan konvensional nilai kekerasan konvensional dalam skala HRC, HV atau HB.
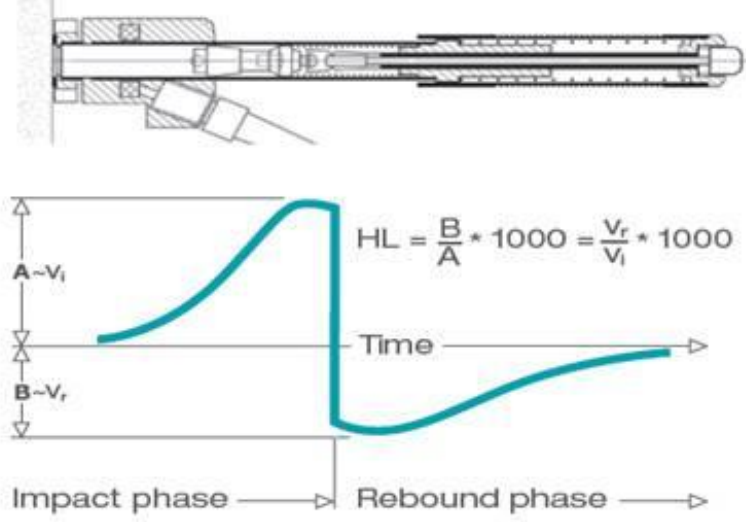

Gambar 2.4 konsep dasar perhitungaan dalam skala Leeb (HL).

\section{Metode Penelitian}

\subsection{Alat dan bahan}

Peralatan dan bahan yang digunakan untuk penelitian ini meliputi aluminium bekas pakai, tanur induksi, pasir silika, bentonite, air , kayu, pola, triplek, ember, timbangan digital, gelas ukur, sarung tangan tahan panas, tang, penjepit crucible,palu dan alat uji kekerasan brinell.

\subsection{Perencanaan pola}
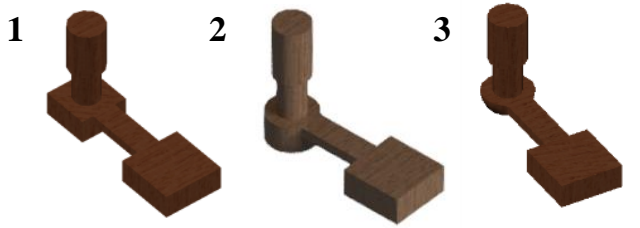

Gambar 3.1 Variasi bentuk sprue well Keterangan :

1. Sprue Well bentuk balok

2. Sprue Well bentuk silinder

3. Sprue Well bentuk setengah bola

\subsection{Langkah Kerja}

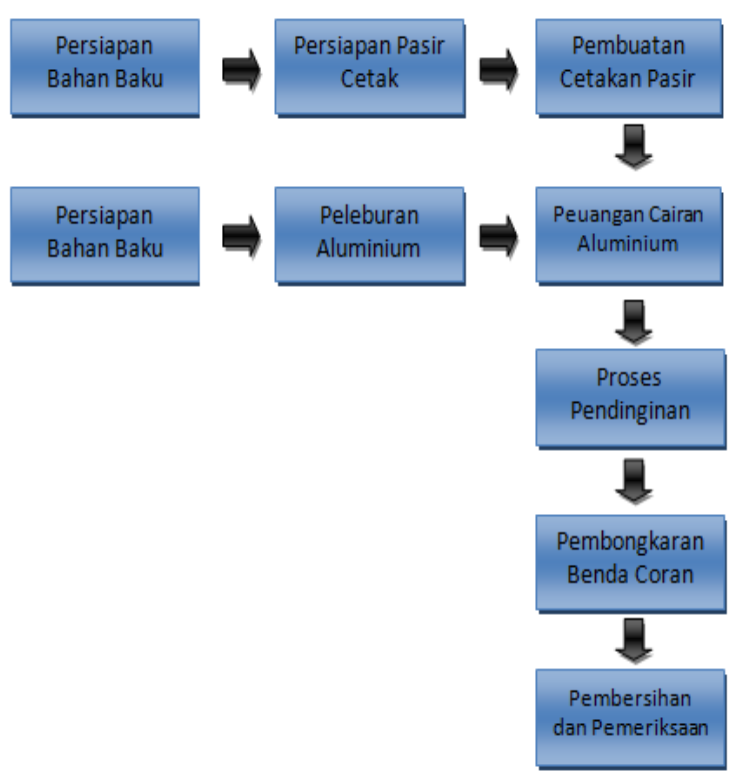

Gambar 3.2 Langkah kerja pengecoran

- Persiapan Bahan Baku

1. Mempersiapkan Pasir silika, Bentonite dan Air untuk bahan pembuatan pasir cetak.

2. Mempersiapkan Almunium bekas kaleng minuman untuk pembutan cairan logam.

\section{Persiapan Pasir Cetak}

1. Persiapkan Pasir Silika 80\%, Bentonite $10 \%$, dan air $10 \%$.

2. Campurkan ketiga material tersebut ke dalam ember, lalu aduk sampai homogen sampai mendapatkan kekerasan pasir yang baik. 
3. Melakukan pengecekan pasir cetak dengan membuat gumpalan pasir yang keras dan padat hingga pasir cetak mempuyai sifat mampu bentuk.

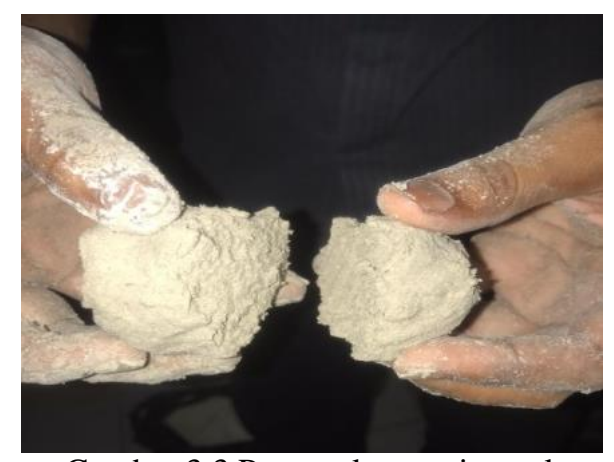

Gambar 3.3 Pengecekan pasir cetak

\section{Pembuatan Cetakan Pasir}

1. Persiapkan rangka cetak bagian bawah dan atas.

2. Persiapkan pola cetakan dan pola saluran.

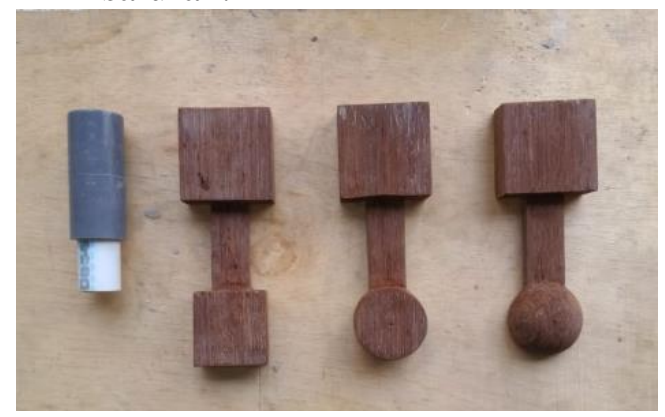

Gambar 3.4 Pola saluran dan pola cetakan

3. Membuat cetakan pasir bagian bawah

Letakan triplek sebagai alas kemudian letakan rangka cetak bagian bawah dan masukan pola cetakan dengan posisi center.

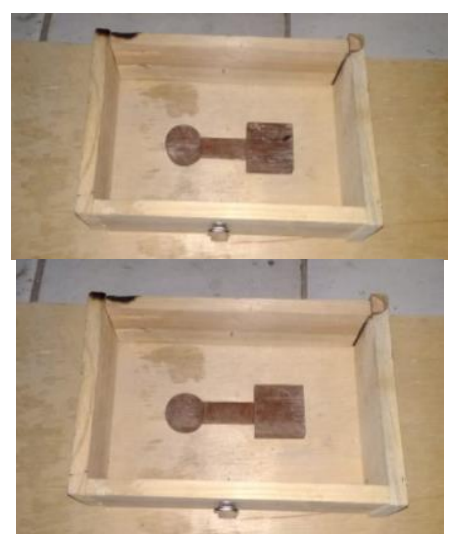

Gambar 3.5 Proses Pembuatan cetakan bawah
Isi pasir cetak ke dalam rangka cetakan yang sudah terisi pola cetakan.

Tumbuk pasir cetak dengan rata pada semua sisi sampai penuh dan padat.

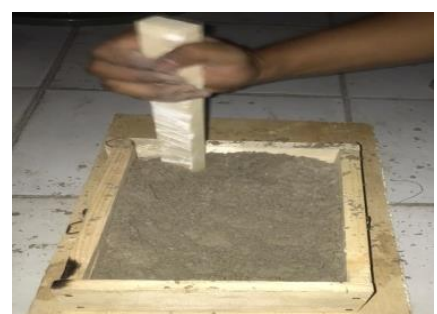

Gambar 3.6 Proses Pemadatan pasir

Balik cetakan pasir, kemudian lepas pola dari pasir cetak secara perlahan menggunakan skrup.

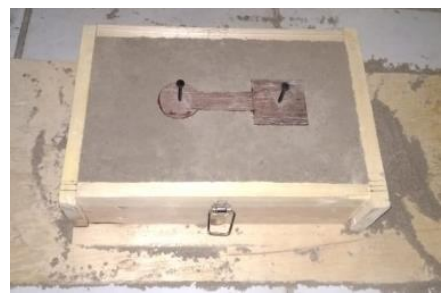

Gambar 3.7 Pelepasan Pola

Bersihkan kotoran dari cetakan pasir.

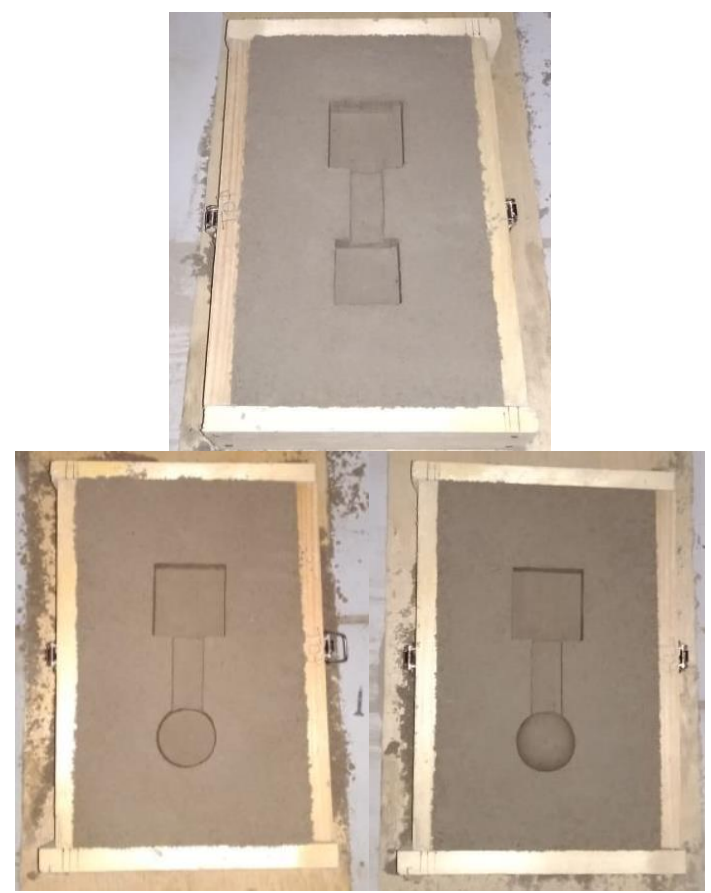

Gambar 3.8 Hasil Pola cetakan

4. Membuat cetakan pasir bagian atas

> Letakan triplek sebagai alas kemudian letakan rangka cetak bagian atas dan masukan pola saluran dengan posisi center terhadap Sprue Well. 
Isi pasir cetak ke dalam rangka cetakan yang sudah terisi pola saluran.

- Tumbuk pasir cetak dengan rata pada semua sisi sampai penuh dan padat.

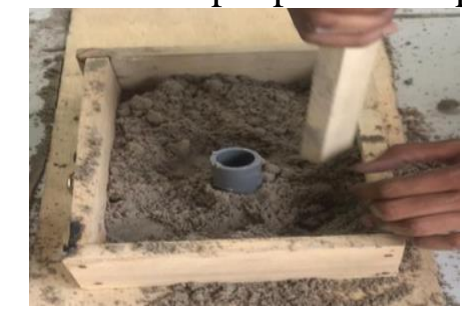

Gambar 3.9 Proses Pemadatan Pasir

Lepaskan pola saluran dengan cara menarik pola saluran secara perlahan

Balik cetakan pasir dan bersihkan dari kotoran.

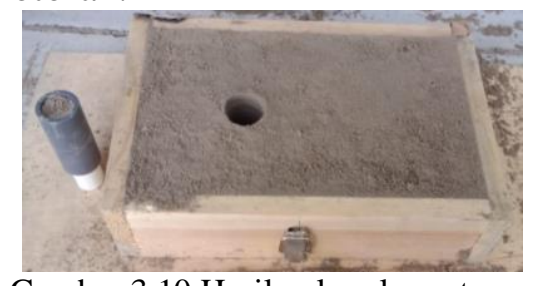

Gambar 3.10 Hasil pola saluran tuang

5. Rakit Cetakan bagian bawah dan atas.

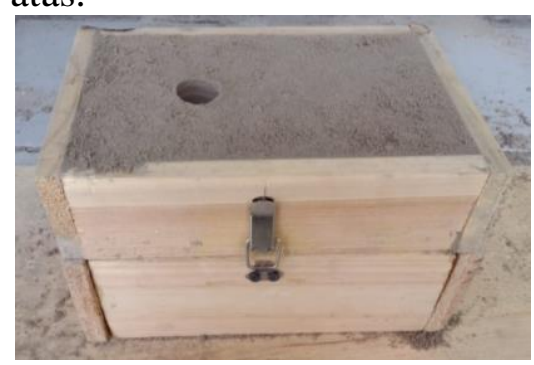

Gambar 3.11 Perakitan cetakan pasir

\section{Peleburan Aluminium}

1. Hidupkan tanur induksi, lalu biarkan sampai temperatur suhu tanur induksi naik sampai $600{ }^{\circ} \mathrm{C}$

2. Masukan logam Aluminium bekas kaleng minuman ke dalam Crucible sedikit demi sedikit sampai kapasitas Crucible terisi penuh.

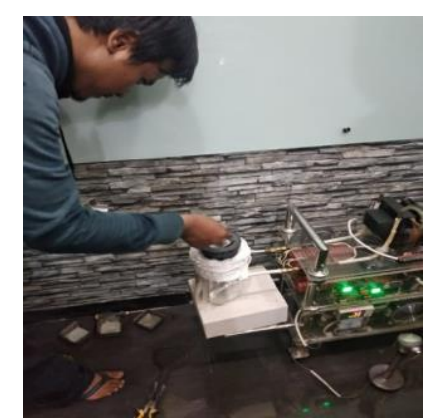

Gambar 3.12 Peleburan Logam
3. Tunggu sampai aluminium mencair sampai temperatur mencapai $660^{\circ} \mathrm{C}$. peleburan Aluminium membutuhkan waktu sampai 2 jam.

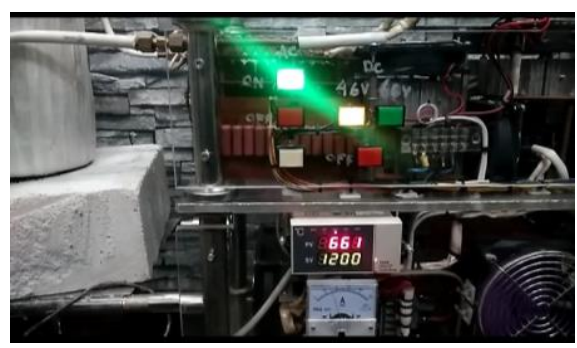

Gambar 3.13 Temperatur cairan logam

4. Bersihkan kotoran yang terdapat pada cairan logam sebelum melakukan proses penuangan.

\section{$>\quad$ Penuangan Cairan Aluminium}

1. Persiapkan Cetakan pasir yang sudah di rakit.

2. Pastikan temperatur peleburan logam aluminium $660^{\circ} \mathrm{C}$.

3. Tuang cairan logam aluminium dan catat waktu untuk masing - masing pola saluran dengan sprue well balok, silinder dan setengah bola sampai terisi penuh.

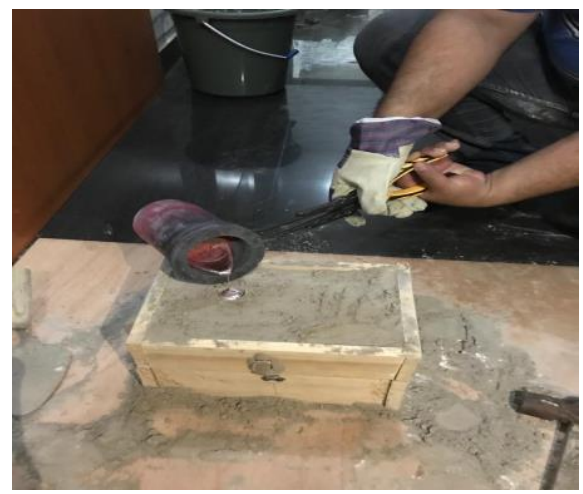

Gambar 3.14 Proses Penuangan

4. Diamkan beberapa saat menggunkan temperatur kamar hingga logam cair membeku dan dingin.

\section{Pembongkaran benda cor}

1. Bongkar cetakan pasir yang sudah terisi benda cor

2. Angkat benda cor menggunakan tang jepit .

3. Bersihkan benda cor dari pasir yang menempel. 


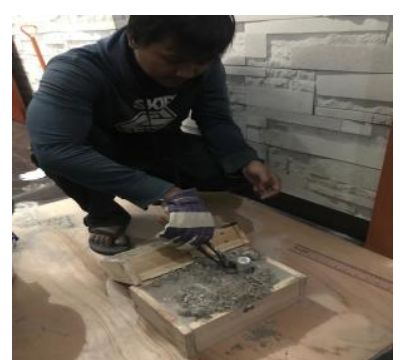

Gambar 3.15 Pembongkaran Benda Cor

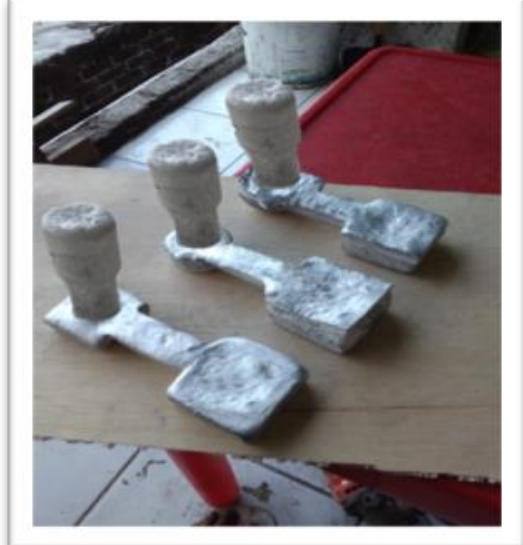

Gambar 3.16 Hasil Benda Cor

\section{Pemeriksaan akhir}

1. Potong saluran tuang benda cor menggunakan gerinda.

2. Bersihkan dan haluskan benda cor menggunakan ampelas halus dari partikel partikel yang menempel.

3. Lakukan uji kekerasan dengan metode Leeb Rebound Hardness.

\subsection{Diagram Alur Penelitian}

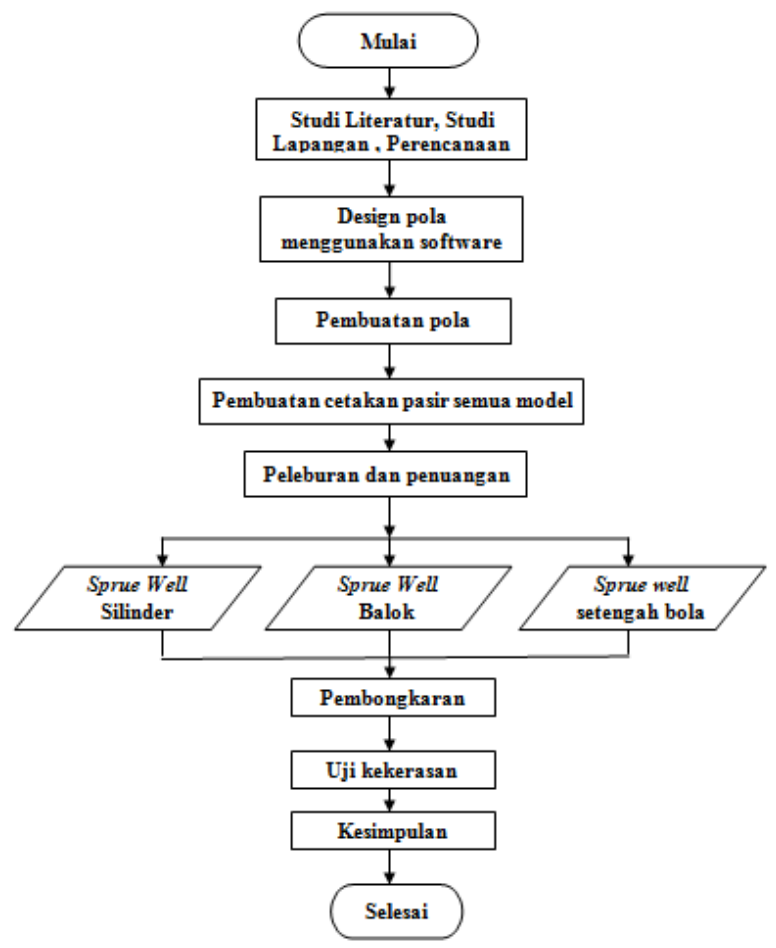

Gambar 3.17 Diagram alur penelitian

\section{HASIL DAN PEMBAHASAN}

\subsection{Analisa aliran fluida}

- Pola saluran bentuk sprue well balok Parameter yang diketahui :

Volume Coran $\left(\mathrm{V}_{\mathrm{c}}\right)=127.854 \mathrm{~cm}^{3}$

$>$ Waktu Tuang $(\mathrm{t}) \quad=7$ detik (menggunakan Stopwatch)

Debit Aliran $(\mathrm{Q})=\frac{\text { Volume Coran }(\mathrm{Vc})}{\text { Waktu Tuang }(\mathrm{t})}=$ $127.854 \mathrm{~cm}^{3}$

$18.26^{\mathrm{cm}^{3}} / \mathrm{s}$

Massa Jenis Cairan $(\rho)=2.35^{\mathrm{g}} / \mathrm{cm}^{3}$

Koefisien Kekentalan $(\mu)$ $=0.0055 \mathrm{~g} / \mathrm{cm}$. s

Tabel 4.1 Hubungan luas penampang dan kecepatan cairan logam ( sprue well balok)

\begin{tabular}{|c|c|c|}
\hline \multirow{2}{*}{ Bagian Benda Cor } & Luas Penampang, A & Kecepatan, v(m/s) \\
\cline { 2 - 3 } & $\left(\mathrm{cm}^{2}\right)$ & $\mathrm{v}=\mathrm{Q} / \mathrm{A}$ \\
\hline Pouring Cup & $6,7 \mathrm{~cm}^{2}$ & $2,73 \mathrm{~cm} / \mathrm{s}$ \\
\hline Sprue & $3,8 \mathrm{~cm}^{2}$ & $4,81 \mathrm{~cm} / \mathrm{s}$ \\
\hline Sprue Well & $16 \mathrm{~cm}^{2}$ & $1,14 \mathrm{~cm} / \mathrm{s}$ \\
\hline Kecepananan \\
\hline Runner & $1,5 \mathrm{~cm}^{2}$ & $12,17 \mathrm{~cm} / \mathrm{s}$ \\
\hline Spesimen & $10 \mathrm{~cm}^{2}$ & $1,83 \mathrm{~cm} / \mathrm{s}$ \\
\hline
\end{tabular}

Jenis Aliran fluida logam 
$\operatorname{Re}=\frac{p \cdot v \cdot d}{\mu}$

$\operatorname{Re}=\frac{2,35 \mathrm{~g} / \mathrm{cm}^{\mathrm{g} \cdot 1,83^{\mathrm{cm} /} / \mathrm{s} \cdot 2,86 \mathrm{~cm}}}{0,0055^{\mathrm{g} / \mathrm{cm} . \mathrm{s}}}$

$\operatorname{Re}=2.236,26<2000-<4000$ ( Aliran Transisi)

Jadi Untuk jenis Aliran fluida logam Aluminium dengan bentuk Sprue Weel balok adalah aliran transisi.

- Pola saluran bentuk sprue well silinder

Parameter yang diketahui :

Volume Coran $\left(\mathrm{V}_{\mathrm{c}}\right)=120.974 \mathrm{~cm}^{3}$

$>$ Waktu Tuang $(\mathrm{t})=6$ detik ( menggunakan Stopwatcth)

Debit Aliran ( Q ) $=\frac{\text { Volume Coran }(V c)}{\text { Waktu Tuang ( } \mathrm{t})}=$ $\frac{120,974 \mathrm{~cm}^{\mathrm{s}}}{6 \mathrm{~s}}=20,16 \mathrm{~cm}^{3} / \mathrm{s}$

Massa Jenis Cairan $(\rho)=2.35^{\mathrm{g}} / \mathrm{cm}^{3}$

Koefisien Kekentalan $(\mu)=$ $0.0055^{\mathrm{g}} / \mathrm{cm}$. s

Tabel 4.2 Hubungan luas penampang dan kecepatan cairan logam ( sprue well silinder)

\begin{tabular}{|c|c|c|c|}
\hline \multirow{2}{*}{ Bagian Benda Cor } & Luas Penampang, A & Kecepatan, $\mathrm{v}(\mathrm{m} / \mathrm{s})$ & \multirow{3}{*}{$\begin{array}{l}\text { Penurunan } \\
\text { Kecepatan }\end{array}$} \\
\hline & $\left(\mathrm{cm}^{2}\right)$ & $\mathrm{v}=\mathrm{Q} / \mathrm{A}$ & \\
\hline Pouring Cup & $6,7 \mathrm{~cm}^{2}$ & $3,01 \mathrm{~cm} / \mathrm{s}$ & \\
\hline Sprue & $3,8 \mathrm{~cm}^{2}$ & $5,31 \mathrm{~cm} / \mathrm{s}$ & \\
\hline Sprue Well & $12,56 \mathrm{~cm}^{2}$ & $1,61 \mathrm{~cm} / \mathrm{s}$ & $70 \%$ \\
\hline Runner & $1,5 \mathrm{~cm}^{2}$ & $13,44 \mathrm{~cm} / \mathrm{s}$ & \\
\hline Spesimen & $10 \mathrm{~cm}^{2}$ & $2,02 \mathrm{~cm} / \mathrm{s}$ & \\
\hline
\end{tabular}

Jenis aliran fluida logam

$\operatorname{Re}=\frac{p \cdot v \cdot d}{\mu}$

$\operatorname{Re}=\frac{2,35^{\mathrm{g}} / \mathrm{cm}^{\mathrm{g} \cdot 2,02^{\mathrm{cm}} / \mathrm{s} \cdot 2,86 \mathrm{~cm}}}{0,0055^{\mathrm{g} / \mathrm{cm} . \mathrm{s}}}$

$\operatorname{Re}=2.468,44<2000-<4000$ ( Aliran Transisi)

Jadi Untuk jenis Aliran fluida logam Aluminium dengan bentuk Sprue Weel silinder adalah aliran transisi.

- Pola saluran bentuk sprue well setengah bola

Parameter yang diketahui :

Volume Coran $\left(\mathrm{V}_{\mathrm{c}}\right)=112,6 \mathrm{~cm}^{3}$
Waktu Tuang $(\mathrm{t})=5$ detik

( menggunakan Stopwatcth)

Debit Aliran ( Q)

$=\frac{\text { Volume Coran }(\mathrm{Vc})}{\text { Waktu Tuang }(\mathrm{t})}=\frac{112,6 \mathrm{~cm}^{\mathrm{a}}}{5 \mathrm{~s}}$

$=$

$22,52 \mathrm{~cm}^{3} / \mathrm{s}$

Massa Jenis Cairan $(\rho)=2.35 \mathrm{~g} / \mathrm{cm}^{3}$

Koefisien Kekentalan $(\mu)=$ $0.0055 \mathrm{~g} / \mathrm{cm} . \mathrm{s}$

Tabel 4. 3 Hubungan luas penampang dan kecepatan cairan logam ( sprue well setengah bola)

\begin{tabular}{|c|c|c|}
\hline \multirow{2}{*}{ Bagian Benda Cor } & Luas Penampang, A & Kecepatan, v(m/s $)$ \\
\cline { 2 - 3 } & $\left(\mathrm{cm}^{2}\right)$ & $\mathrm{v}=\mathrm{Q} / \mathrm{A}$ \\
\hline Pouring Cup & $6,7 \mathrm{~cm}^{2}$ & $3,36 \mathrm{~cm} / \mathrm{s}$ \\
\hline Sprue & $3,8 \mathrm{~cm}^{2}$ & $5,93 \mathrm{~cm} / \mathrm{s}$ \\
\hline Sprue Well & $6,28 \mathrm{~cm}^{2}$ & $3,59 \mathrm{~cm} / \mathrm{s}$ \\
\hline Runner & $1,5 \mathrm{~cm}^{2}$ & $15,01 \mathrm{~cm} / \mathrm{s}$ \\
\hline Spesimen & $10 \mathrm{~cm}^{2}$ & $2,25 \mathrm{~cm} / \mathrm{s}$ \\
\hline
\end{tabular}

Jenis aliran fluida logam

$\operatorname{Re}=\frac{p \cdot v \cdot d}{\mu}$

$\operatorname{Re}=\frac{2,35 \mathrm{~g} / \mathrm{cm}^{\mathrm{s} .2,25 \mathrm{~cm} / \mathrm{s} .2,86 \mathrm{~cm}}}{0,0055^{\mathrm{g} / \mathrm{cm}, \mathrm{s}}}$

$\mathrm{Re}=2.749,5<2000-<4000$ ( Aliran Transisi)

Jadi Untuk jenis Aliran fluida logam Aluminium dengan bentuk sprue weel setengah bola adalah aliran transisi.

Tabel 4.4 Hubungan bentuk sprue well terhadap kecepatan akhir dan Reynold Number

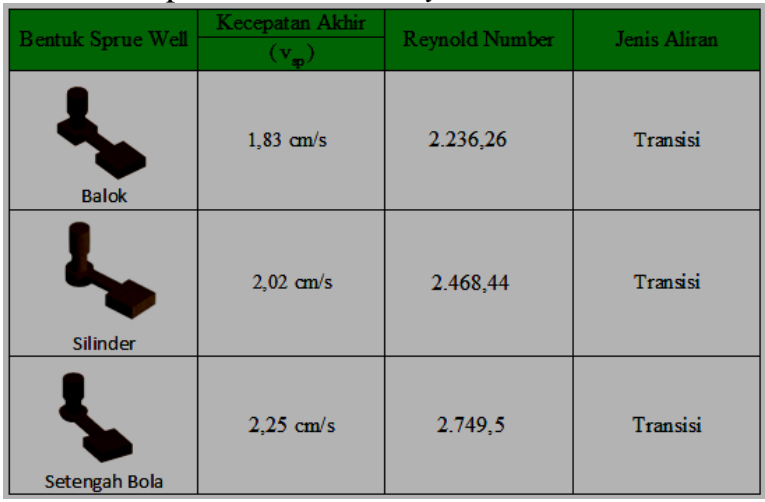




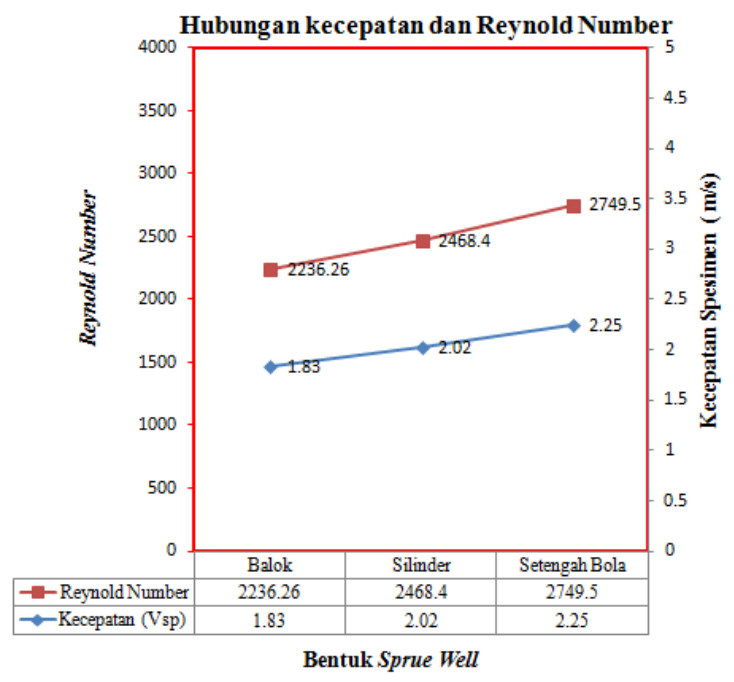

Gambar 4.1 Hubungan kecepatan dan bilangan Reynolds

Hasil Analisa aliran fluida logam aluminium pada sistem saluran dengan sprue well berbentuk balok, silinder, dan setengah bola dengan waktu penuangan 7 detik, 6 detik dan 5 detik masing -masing mempunyai nilai persentase penurunan kecepatan yaitu $76 \%, 70 . \%$ dan $40 \%$. Dan menunjukan bahwa sistem saluran dengan sprue well berbentuk Balok mempunyai nilai kecepatan akhir 1.83 $\mathrm{cm} / \mathrm{s}$ dan bilangan Reynold 2236.26 dengan jenis aliran transisi diikuti sistem saluran berbentuk silinder dengan kecepatan akhir $2.02 \mathrm{~cm} / \mathrm{s}$ dan bilangan Reynolds 2468.4 dengan jenis aliran transisi, serta sistem saluran dengan sprue well berbentuk setengah bola mempunyai nilai kecepatan akhir $2.25 \mathrm{~cm} / \mathrm{s}$ dan bilangan Reynold 2749.5 dengan jenis aliran transisi.

Berdasarkan data tersebut menunjukan bahwa sistem saluran dengan sprue well berbentuk silinder mempunyai nilai kecepatan dan bilangan Reynold tertinggi , diikuti sistem saluran dengan sprue well berbentuk silinder . serta sistem saluran dengan sprue well berbentuk balok mempunyai nilai kecepatan dan bilangan Reynold terendah.

\subsection{Pengujian Kekerasan (Leeb Ribbon Hardness) \\ Pengujian kekerasan menggunakan metode Lebb Rebound Hardness dengan}

menguji 9 titik pada bagian spesimen untuk sprue well balok, silnder dan setengah bola.

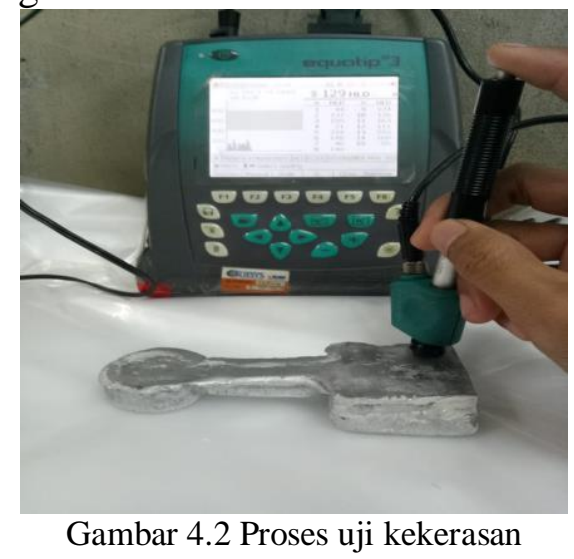

Hasil Uji kekerasan yang dilakukan pada masing- masing spesimen dengan melakukan uji kekerasan pada 9 titik , menunjukan bahwa sistem saluran dengan bentuk sprue well setengah bola mempunyai nilai kekerasan yang paling rendah yaitu 121.4 HLD diikuti bentuk silinder 148,2 HLD serta yang paling tinggi berbentuk balok yaitu 175.4 HLD.

Hal tersebut dikarenakan proses laju aliran kecepatan cairan logam pada sistem saluran berbentuk Setengah Bola mempunyai nilai yang paling tinggi dan mempunyai nilai Reynold tertinggi sehingga nilainya mendekati jenis aliran turbulen yang dapat yang menyebabkan laju aliran logam tidak stabil, sehingga distribusi aliran cairan logam tidak merata.

\section{KESIMPULAN DAN SARAN}

\subsection{KESIMPULAN}

Setelah melakukan eksperimen sistem saluran dengan bentuk sprue well yang berbeda dapat disimpulkan bahwa :

1. Bentuk sprue well pada sistem saluran mempunyai pengaruh terhadap nilai kecepatan aliran Fluida logam dan bilangan Reynold.

2. Kecepatan aliran fluida logam pada bagian sprue well bentuk balok, silinder dan setengah bola dapat menurunkan kecepatan masing masing yaitu $76 \%, 70 \%$ dan $40 \%$. 
3. Sistem saluran dengan sprue well berbentuk balok, silinder dan setengah bola mempunyai nilai kecepatan aliran fluida logam aluminium dan bilangan Reynold masing - masing yaitu $1,83 \mathrm{~cm} / \mathrm{s}$ dan 2.236,36 ( aliran transisi ), 2,02 cm/s dan 2.468,4 ( aliran transisi ), serta $2,25 \mathrm{~cm} / \mathrm{s}$ dan 2.749,5 ( aliran transisi ) .

4. Spesimen aluminium hasil pengecoran sand casting dengan sistem saluran berbentuk sprue well balok, silinder dan setengah bola masing-masing mempunyai nilai kekerasan yaitu 175,4 HLD, 148,2 HLD dan 121,4 HLD.

\subsection{SARAN}

Adapun saran yang dapat diberikan sebagai berikut :

1. Penelitian selanjutnya dengan eksperimen bentuk saluran yang berbeda dapat menggunakan dengan metode pengecoran lain dan material yang berbeda.

2. Penelitian ini dapat dilanjutkan dengan pengujian struktur mikro dan sifat mekanik lainnya, dan selanjutnya dapat disimulasikan dengan beberapa software casting.

3. Performa Furnace atau Tanur Induksi bisa didisain untuk dinaikkan temperaturnya di atas $1000^{\circ} \mathrm{C}$ agar bisa melebur logam ferro kemudian di lakukan uji performance.

\section{DAFTAR PUSTAKA}

Ardhiyanto, N.K., 2011, Pengaruh Bentuk Penampang Saluran Turun (Sprue)Terhadap Cacat Porositas, Batas Butir dan, Kekerasan Pada Pengecoran Aluminium Paduan Dengan Cetakan Pasir. Skripsi.UNS, Surakarta.

Basori, B. (2018). Pengaruh Media Quenching terhadap Kekerasan dan Struktur Mikro Paska Hardfacing. Jurnal Kajian Teknik Mesin, 3(2), 66-72.
Indra, Ahmad S. \& Ridwan (2012) "Analisa Aliran Fluida Pada Pipa SpiralDengan Variasi Diameter Menggunakan Metode Computational Fluid Dinamics (CFD)" Jurusan Teknik Mesin, Fakultas Teknologi Industri, Universitas Gunadarma

Kalpakjian, S. \& Schmid, S. R. (2009). Manufacturing Engineering And Technology.(6thed). Malaysia: University Teknologi

Pratama, Rizal., Soeharto., 2012, Studi Eksperimen Pengaruh Jenis Saluran Pada Aluminium Sand Casting Terhadap Porositas Produk Toroidal Piston, Jurnal Teknik ITS, 1,1, 126-130.

Prijono, K., \& Suhadi, A. (2018). Pengaruh Suhu Sintering Terhadap Kekerasan Paduan Mikro Fe-cr Hasil Metode Ultrasonik. Jurnal Kajian Teknik Mesin, 3(2), 89-97.

Roziqin, K., Purwanto, H.\&Syafa'at, I. (2012).Pengaruh Model Sistem Saluran Pada Proses Pengecoran Aluminium Daur Ulang Terhadap Struktur Mikro Dan Kekerasan Coran Pulli Diameter $76 \mathrm{Mm}$ Dengan Cetakan Pasir. Vol.8. Semarang: Universitas Wahid Hasyim.

Santoso, J. (2012). Pengaruh Bentuk Penampang Runner terhadap Cacat Porositas dan Nilai Kekerasan Produk Cor Aluminium Cetakan Pasir. Universitas Sebelas Maret, Surakarta, Indonesia.

Surdia T, Chijiwa K, 1986, "Teknik Pengecoran Logam" , Pradnya Paramitha, Jakarta.

Wibowo, A. (2017). Modifikasi dimensi desain Runner dan Sprue Well pada Gravity Die Casting Timah Putih untuk Mengurangi Waste Material dan Porositas. Surabaya: Universitas Kristen Petra 